\title{
ARTICLE
}

\section{Particulate matter concentrations during winter seasons of 2016-2020 in Ulaanbaatar, Mongolia}

\author{
Ganzorig Byambajav ${ }^{1,2}$, Bayarmaa Batbaatar ${ }^{2}$, Ariundelger Ariunsaikhan ${ }^{2}$ and Sonomdagva Chonokhuu ${ }^{1,2 *}$ \\ ${ }^{1}$ Department of Environment and Forest Engineering, School of Engineering and Applied Sciences, \\ National University of Mongolia, Ulaanbaatar, Mongolia. \\ ${ }^{2}$ Laboratory of Air and Environmental Monitoring, Graduate School, \\ National University of Mongolia, Ulaanbaatar, Mongolia.
}

ARTICLE INFO: Received: 25 Oct, 2020; Accepted: 29 Mar, 2021

Abstract: In this study, we have focused on the outdoor concentration of fine particulate matter (PM2.5) during the coldest months (November-February) of 2016-2019 and January-February of 2020 and illustrated the daily, monthly and quarterly averages according to the single-point measurement data collected by the PM2.5 sensor at an air quality monitoring station located in a central area of Ulaanbaatar. The study also analyzes monthly high, low, average and median points of PM 2.5 concentrations in the area that was selected. The PM 2.5 sensor collects its data at an interval of every ten seconds, registers 8500 data in one day and presents the concentration of fine particulate matter in micrograms per cubic meter $\left(\mu \mathrm{g} / \mathrm{m}^{3}\right)$. On the basis of data collection and analysis, from November through February of 2019-2020, average PM2.5 concentration dropped noticeably by 44 per cent compared to the previous years. The Government of Mongolia took immediate action to combat air pollution of Ulaanbaatar city in May 2019 by banning the burning of raw coal in the ger districts, which account for 70 per cent of the city's emissions, and introduced coal briquette as the only type of fuel that was allowed to be burned in metal stoves as a primary source of heating and cooking. Our study reveals that the latest government regulation had a considerable impact on air quality during winter 2019-2020 and helped in the sudden decline of the most dangerous pollutant PM2.5 concentration very close to national standards (50 $\mu \mathrm{g} / \mathrm{m}^{3} 24$-hour mean) within 6 months since the enforcement of the new regulation.

Keywords: PM2.5; air pollution; winter pollution; daily average; monthly average; air quality standards; Ulaanbaatar;

\section{INTRODUCTION}

Mongolia is one of the largest landlocked countries, situated in the heart of Eurasia, surrounded by high mountain ranges and elevated at 1.5 kilometers above mean sea level. All of these result in the entire territory to have a severe and harsh continental climate [1].

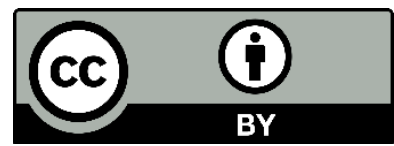

The Author(s). 2021 Open access This article is distributed under the terms of the Creative Commons Attribution 4.0 International License (https://creativecommons.org/licenses/by/4.0/), which permits unrestricted use, distribution, and reproduction in any medium, provided you give appropriate credit to the original author(s) and the source, provide a link to the Creative Commons license, and indicate if changes were made. 
The main characteristics of the climate in Mongolia are short dry summers, considerably cold and lengthy winters, and significantly fluctuating period of spring and fall seasons from year to year [2]. One of the most critical issues of the country has been air pollution, especially in the densely populated urban areas. The level of increase in pollution is mainly influenced by such factors as population density, the growing size of "ger" districts, coal consumption, automobile exhaust emissions and temperature inversion caused by the above geographical features and wind stability [3]. In Ulaanbaatar, the capital of Mongolia, 70 per cent of the pollution emission comes from ger districts, which have been burning coal for heating and cooking, and about 3200 nonhousehold heating stoves, 15 per cent is from over 400,000 vehicles on the road, 10 per cent is from power plants, and the remaining 5 per cent is from ashes, road dust, and unprocessed waste disposal sites [4].

Air pollution of Ulaanbaatar increases in October and its peak period is in December and January. On the other hand, the highest concentration of $\mathrm{PM}_{2.5}$ occurs in January of each year, and according to the average of the last eight years, we found that $\mathrm{PM}_{2.5}$ concentration is 12 times higher than [5] the Mongolian air quality standard $\left(50 \mu \mathrm{g} / \mathrm{m}^{3} 24-\right.$ hour mean) [6] and 25 times higher than that stated in the World Health Organization (WHO) air quality guidelines $\left(25 \mu \mathrm{g} / \mathrm{m}^{3} 24-\right.$ hour mean) [7]. As of 1January, 2020, the total population of Ulaanbaatar was $1,466,125$, of whom 24.3 per cent are children aged 0-9 [8]. According to the study, air pollution exposure for young ages may increase the probability of being vulnerable to future chronic diseases [9]. About 3 billion people out of 7 billion on Earth

\section{MATERIALS AND METHODS}

\section{Study area}

The study area, Building-3 of National University of Mongolia, is located in the central part of Ulaanbaatar. are under influence of air pollutants, such as kerosene, coal and other fossil fuels by burning them in stoves. On a global scale, 3.8 million people die prematurely because of air pollution, while 27 per cent of this death is caused by respiratory infectious disease, another 27 per cent from heart disease, 18 per cent from chronic obstructive pulmonary disease, 20 per cent from stroke, and 8 per cent from lung cancer. Moreover, about one half of the children aged up to 5 years who prematurely died from pneumonia are caused by indoor and outdoor household air pollution [10].

Sonomdagva Ch., et al., (2016) have revealed that $\mathrm{PM}_{2.5}$ in Ulaanbaatar was far higher than the Mongolian air quality standard between 2009 and 2015 [11]. Also, Nakoa M., et al., (2017) reported that daily means of $\mathrm{PM}_{2.5}$, during the survey in the cold season $(94.3 \pm 45.3$ $\mu \mathrm{g} / \mathrm{m}^{3}$ ), was significantly higher than in the warmer season [12]. The government of Mongolia has implemented a number of projects and regulations to reduce winter air pollution. One of the most recent actions prohibited the use of raw coal and replacing it with coal by-product or coal briquette [13]. Since 15 May 2019, the consumption of raw coal was banned in the ger district areas in Ulaanbaatar, which resulted in considerable improvement in the air quality index of fine particulate matter.

The objective of this study is to estimate the long-term concentration of outdoor fine particles, compare annual, quarterly, monthly and daily means, and analyze the outcomes. Also, we evaluated the $\mathrm{PM}_{2.5}$ concentration reduced by using coal briquette according to the Government decision, which was effective during the 2019-2020 winter time.

At the top of this building, a $\mathrm{PM}_{2.5}$ air quality monitoring station is located (Figure 1). 

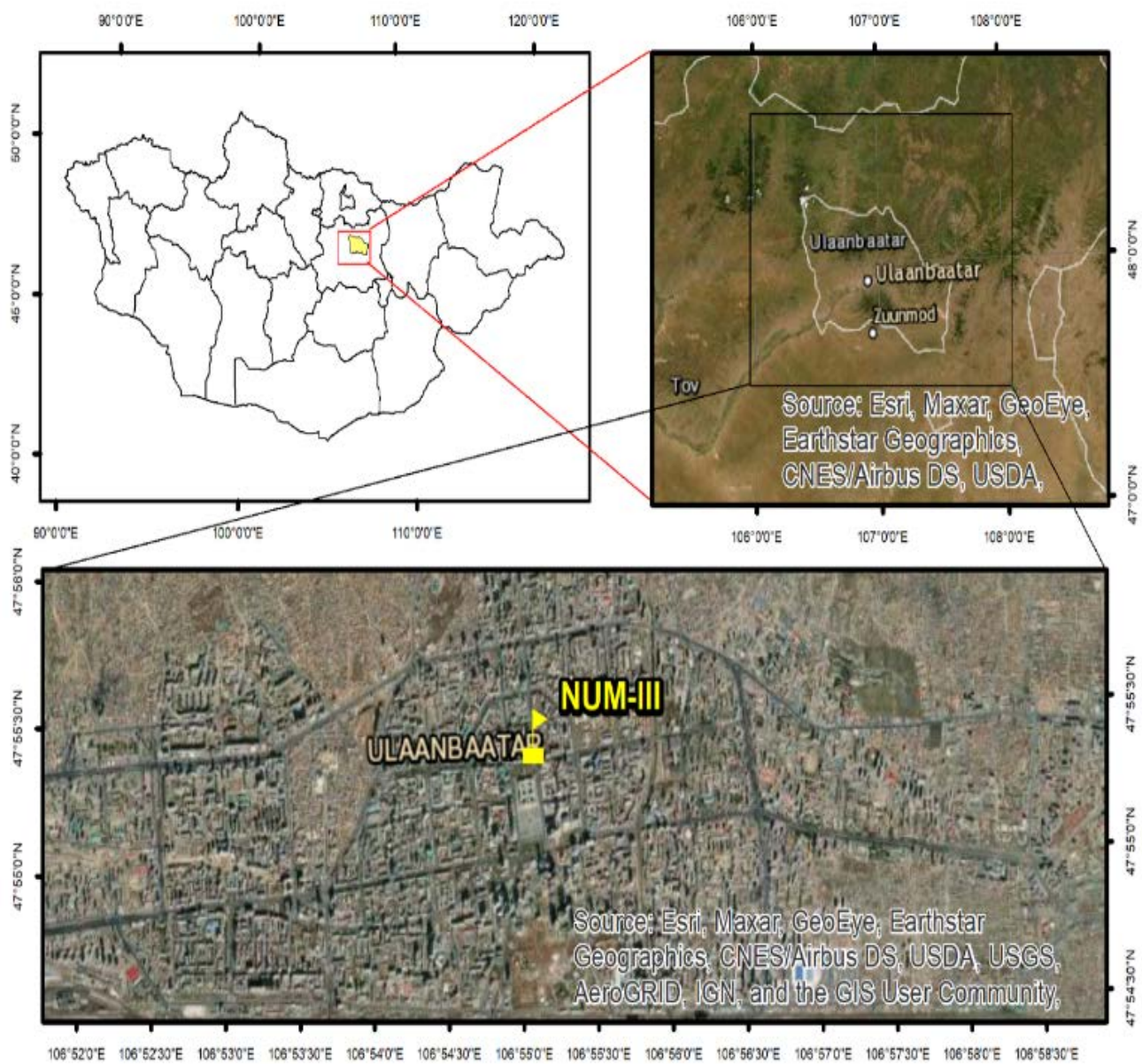

Figure 1. The location of the study area (A. Mongolia) (B. Ulaanbaatar) (C. Monitoring point)

\section{Equipment}

Figure 2 shows the $\mathrm{PM}_{2.5}$ sensor and its measurement data collected at every 10 -second interval, which shows concentration amount of $\mathrm{PM}_{2.5}$ in $\mu \mathrm{g} / \mathrm{m}^{3}$ and registers 8500 measurement data per day [14]. The $\mathrm{PM}_{2.5}$ concentration was determined by the distribution of lightscattering technology. The validation of the

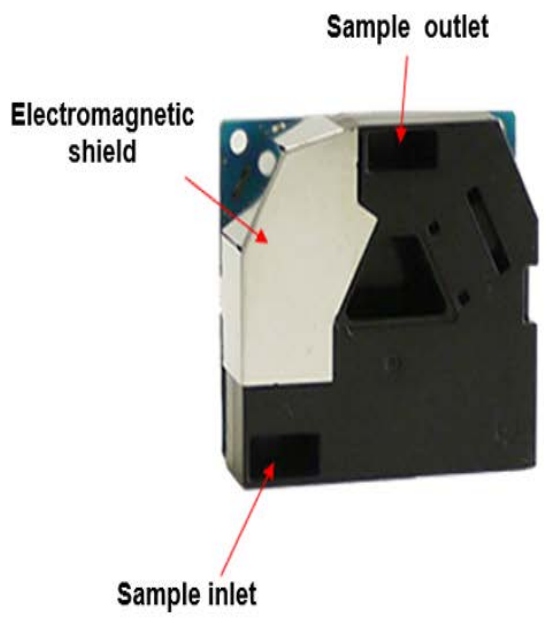

Figure 2. A.PM2.5 sensor
$\mathrm{PM}_{2.5}$ sensor was carried out with beta attenuation monitoring (BAM) instruments (Thermo Fisher, SHARP 5030, DKK-TOA, model FPM-377, and Kimoto, model PM-712) at four urban and suburban sites in Japan. The $\mathrm{PM}_{2.5}$ sensor was designed by Nagoya University and Panasonic Corporation, Japan.

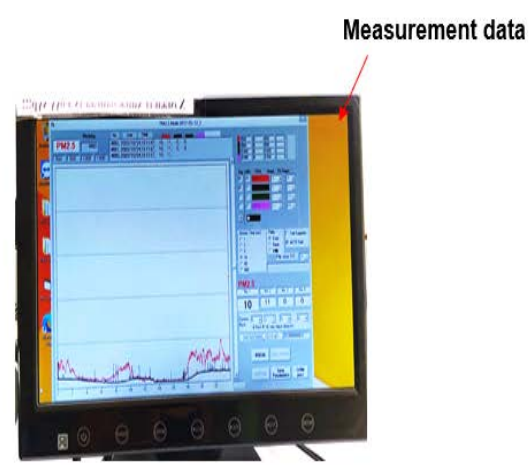

B. Measurement data 
Data extraction and processing: We identified monthly and daily maximum, minimum, average and median points of $\mathrm{PM}_{2.5}$, and compared with air quality standard, and studied the long-term process of the particulate matter. Also, each $15^{\text {th }}$ of the winter months was chosen as a representative day.

\section{RESULTS AND DISCUSSION}

In this study, the long-term data of outdoor ambient $\mathrm{PM}_{2.5}$ has been collected by the sensor at one particular location in
Ulaanbaatar. The daily, monthly and seasonal variations of $\mathrm{PM}_{2.5}$ were illustrated in this section.

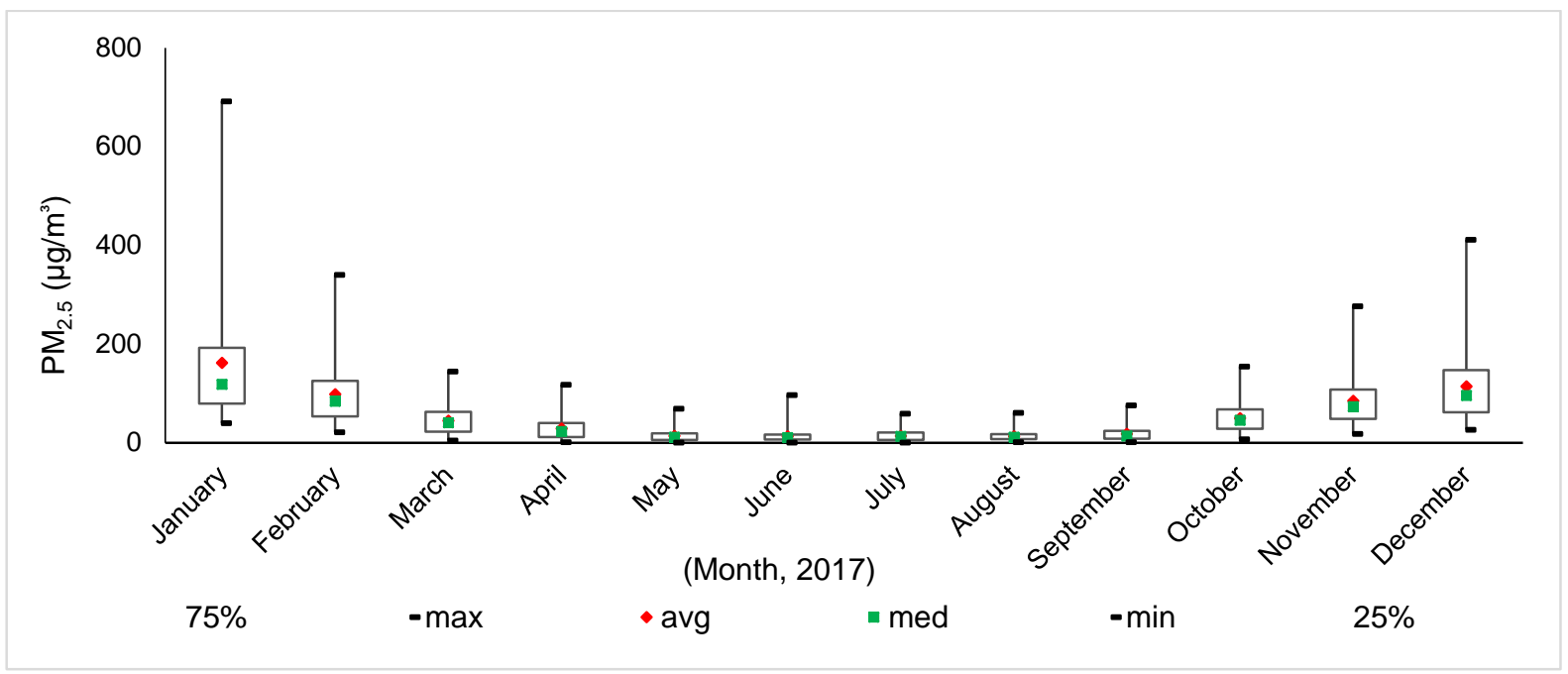

Figure 3. Monthly concentrations of PM 2.5 in 2017

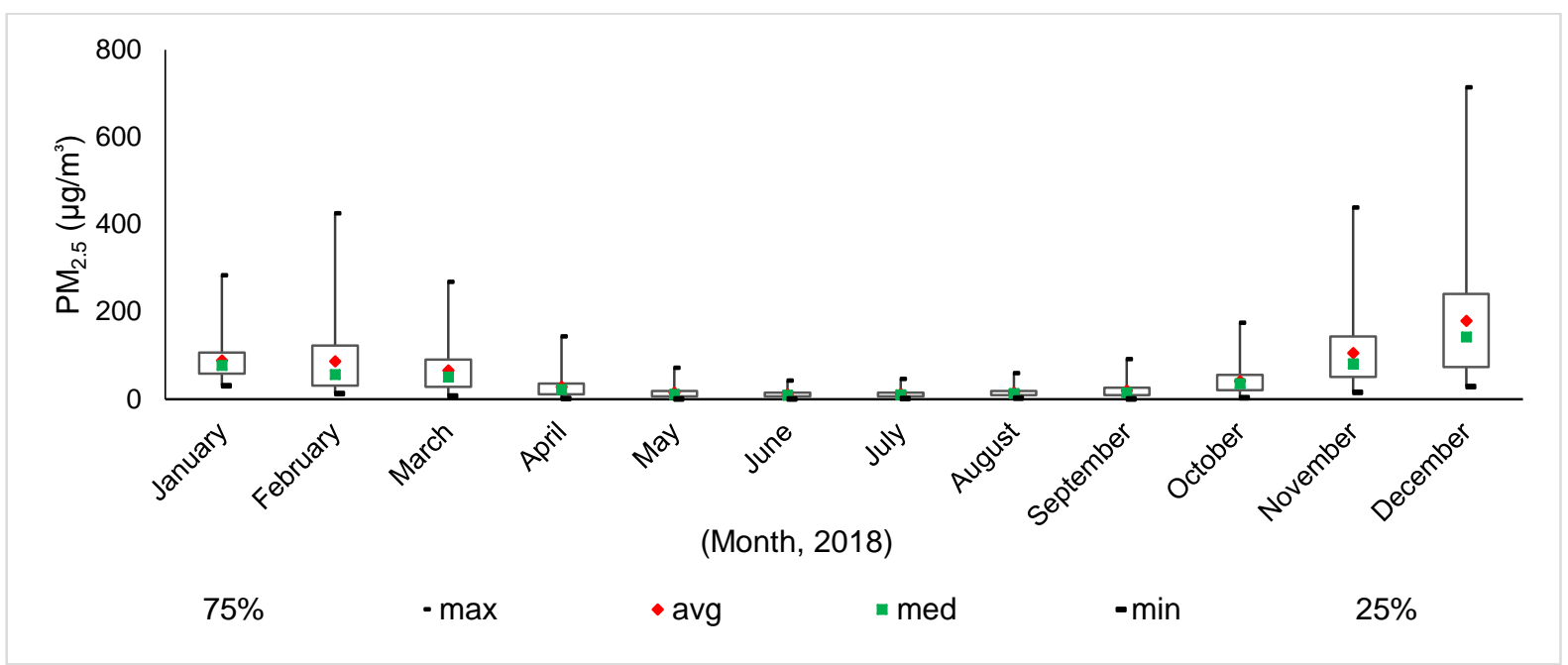

Figure 4. Monthly concentrations of PM..5 in 2018

According to Figure 3, the highest concentration occurred in January through December. The highest concentration of $\mathrm{PM}_{2.5}$, which reached $713 \mu \mathrm{g} / \mathrm{m}^{3}$ in January, was the overall annual highest level and the monthly average was $161 \mu \mathrm{g} / \mathrm{m}^{3}$. Furthermore, in February, the monthly average dropped by 1.6 times to $100 \mu \mathrm{g} / \mathrm{m}^{3}$ compared to January. In
November, the highest point reached $276 \mu \mathrm{g} / \mathrm{m}^{3}$ and the monthly average was $84 \mu \mathrm{g} / \mathrm{m}^{3}$; however, in December, the average point increased to $114 \mu \mathrm{g} / \mathrm{m}^{3}$. For the other months of 2017, although the highest point of $\mathrm{PM}_{2.5}$ concentration exceeded the air quality standard (50 $\mu \mathrm{g} / \mathrm{m}^{3} 24$-hour mean), the monthly averages 
were within the allowed range; so, the study did not focus on those months.

In 2018 (Figure 4), the monthly averages were also above the air quality standard. In January, the highest concentration of $\mathrm{PM}_{2.5}$ reached $283 \mu \mathrm{g} / \mathrm{m}^{3}$, and the monthly high of February was even higher, which was 438 $\mu \mathrm{g} / \mathrm{m}^{3}$. The highest point in November was measured as $438 \mu \mathrm{g} / \mathrm{m}^{3}$, which indicates 8.7 times more than the air quality standard and the monthly average was $106 \mu \mathrm{g} / \mathrm{m}^{3}$. And more interestingly, the average point in December even increased by 6 times compared to November and the monthly high reached 713 $\mu \mathrm{g} / \mathrm{m}^{3}$. However, March-October monthly averages did not exceed the standard.

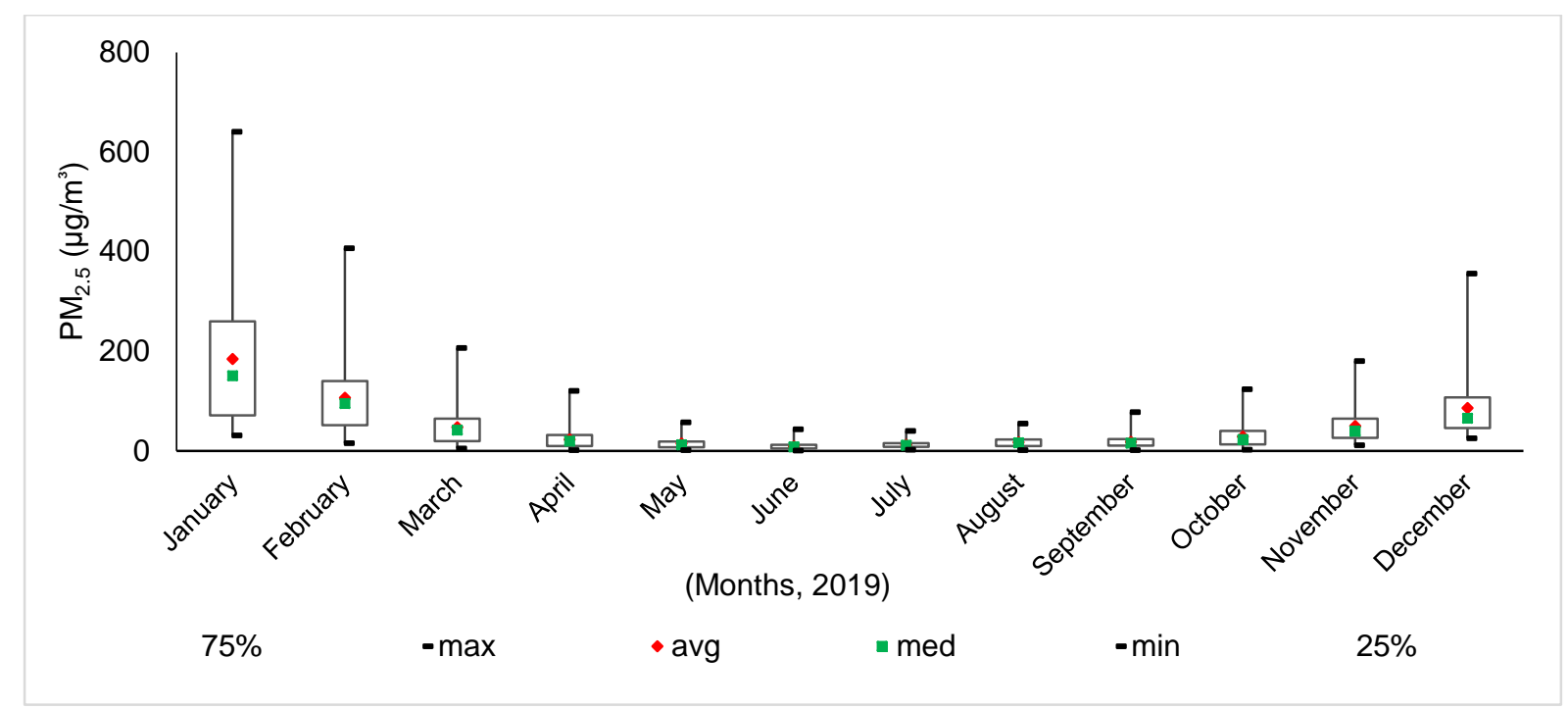

Figure 5. Monthly concentrations of PM 2.5 in 2019

Figure 5 indicates the monthly concentration of $\mathrm{PM}_{2.5}$ in 2019 with the average points of $\mathrm{PM}_{2.5}$ exceeding $50 \mu \mathrm{g} / \mathrm{m}^{3}$ in January, February and December. In addition, among the sampling data collected for last several years, Figure 5 also shows that the amount of $\mathrm{PM}_{2.5}$ in the study area of Ulaanbaatar exceeded the standard $50 \mu \mathrm{g} / \mathrm{m}^{3}$ from November to February, whereas a monthly average of $\mathrm{PM}_{2.5}$ concentration in November 2019 did not exceed the standard level and it even decreased by 2 times compared to November months of 20162018. However, in January 2019, it reached the highest point of $640 \mu \mathrm{g} / \mathrm{m}^{3}$, which was also the annual high, and average point of concentration was $184 \mu \mathrm{g} / \mathrm{m}^{3}$.

Furthermore, the concentration of fine particles decreased by 3 times in December 2019 in comparison with previous years and the monthly average of $\mathrm{PM}_{2.5}$ concentration became $85 \mu \mathrm{g} / \mathrm{m}^{3}$. Thus, in comparison with the previous years, November and December of 2019 happened to be very distinctive months to have a significant decrease in the amount of $\mathrm{PM}_{2.5}$ concentration. 


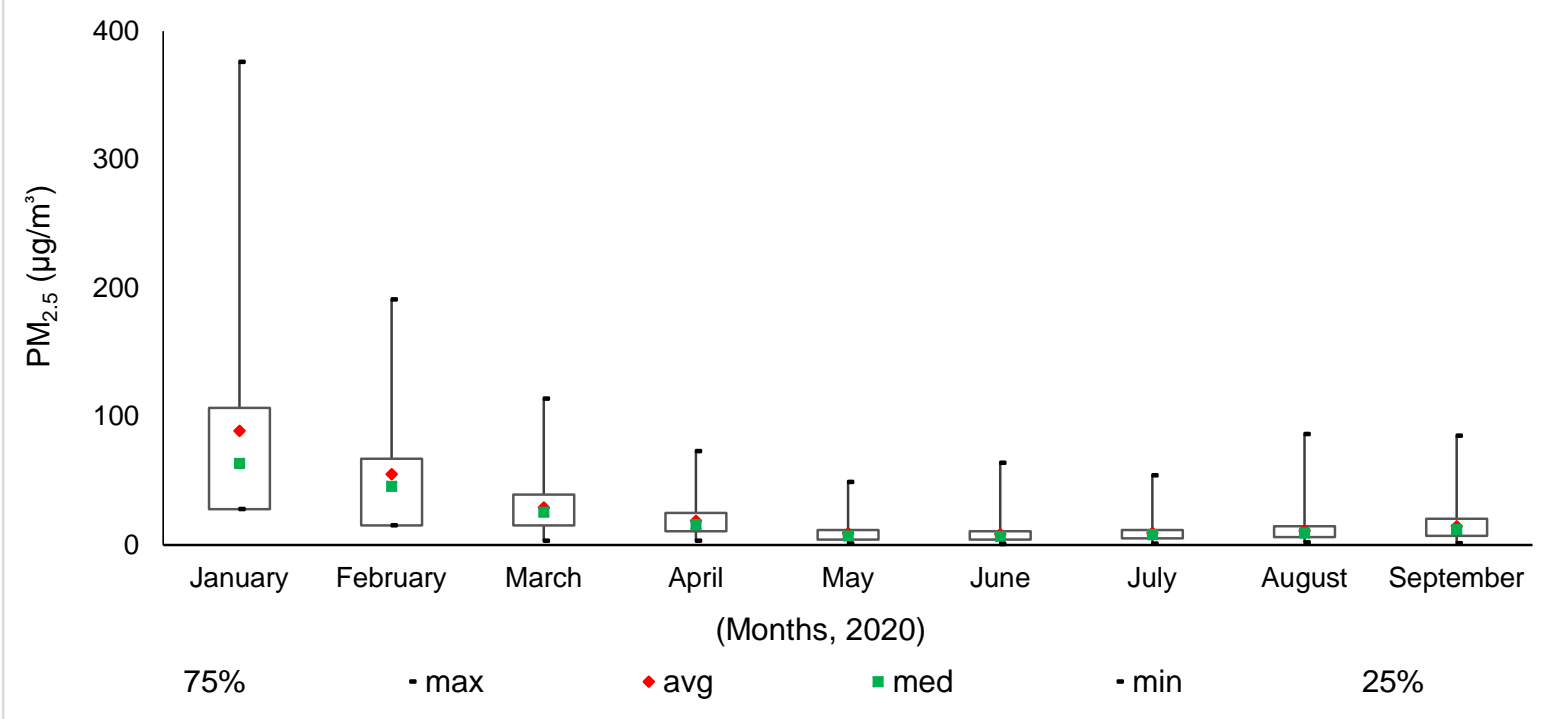

Figure 6. Monthly concentrations of $P M_{2.5}$ in 2020

Figure 6 shows the monthly comparisons of January through September 2020. January 2020 reached the overall high of $376 \mu \mathrm{g} / \mathrm{m}^{3}$ and the monthly average of $88 \mu \mathrm{g} / \mathrm{m}^{3}$. If we compare these points to January of 2017 and 2019, the highest point of concentration decreased by 6 times, monthly average decreased by 2.5 times and the duration of concentration had also shortened. In Figure 3 to Figure 6, we emphasized November-February (coldest periods with highest concentration of $\mathrm{PM}_{2.5}$ ) because the monthly averages of particulate matter in the other months did not exceed the air quality standards. October through December period is not shown here because this period is not covered by the collected data samplings for this study. It will be covered as a part of our future studies illustrating winter 2020-2021.

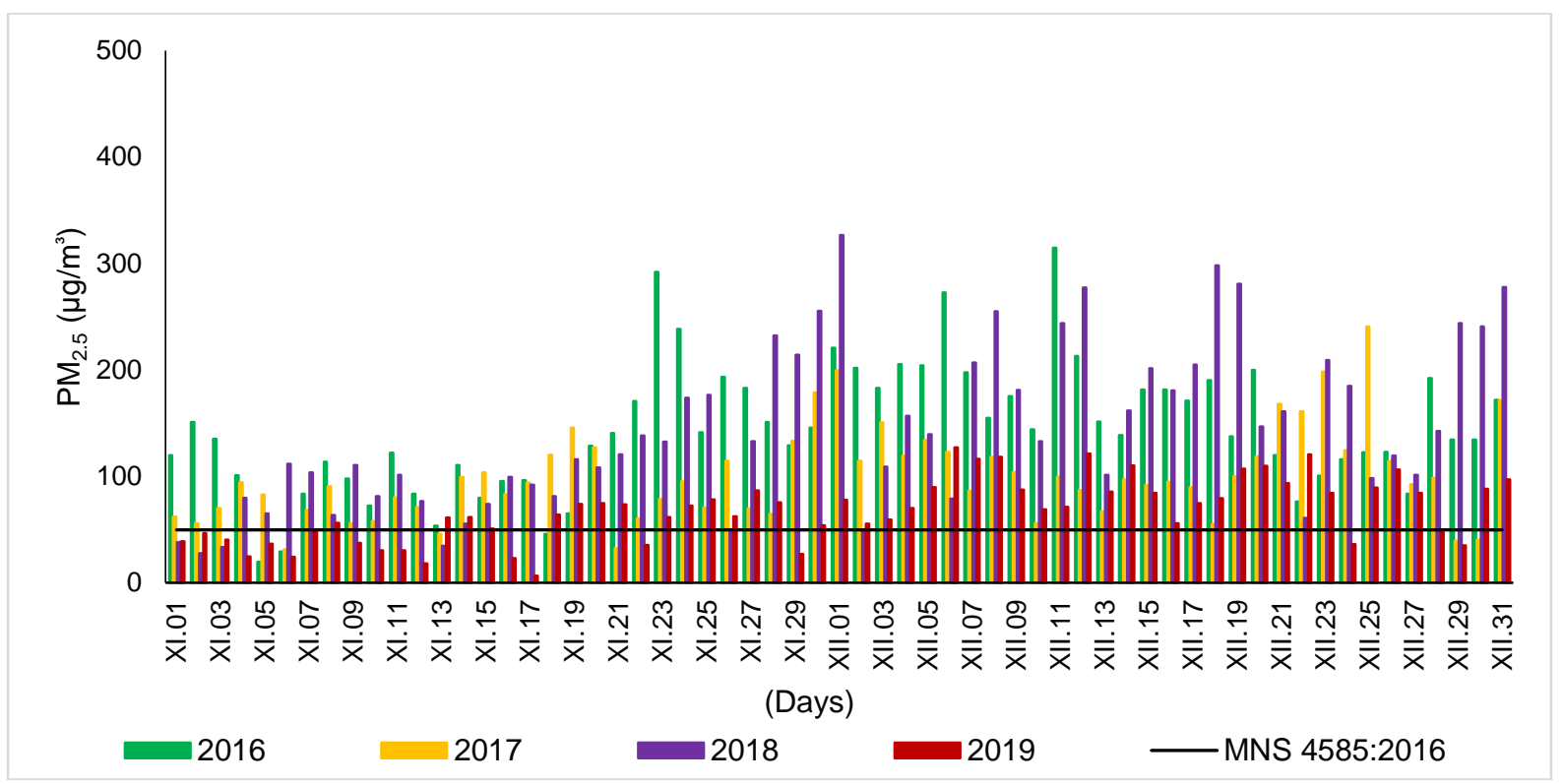

Figure 7. Daily concentration of PM $M_{2.5}$ from November 1st to December 31 ${ }^{\text {st }}$, 2016-2019

Figure 7 illustrates $\mathrm{PM}_{2.5}$ concentration in November and December of 2016-2020 with particular dates shown. The horizontal line indicates the standard line of air quality index.
In November 2016, the concentration of $\mathrm{PM}_{2.5}$ was above the standard line for 27 days while the remaining 3 days had acceptable amounts. The average temperature of the month was - 
$13.7^{\circ} \mathrm{C}$ and monthly precipitation was $18.4 \mathrm{~mm}$. December 2016 was identified because that the amount $\left(150 \mu \mathrm{g} / \mathrm{m}^{3}\right)$ exceeded 3 times higher than the standards during all these 31 days. The fact that the average temperature of the month was $-16.5^{\circ} \mathrm{C}$ and precipitation was $1.1 \mathrm{~mm}$ actually became the reason for the increase in particulate matter.

November and December of 2017 periods had even and similar concentration and also had less daily concentration than in December 2016. The monthly average temperature of those months ranged between $12.2^{\circ} \mathrm{C}$ and $16.7^{\circ} \mathrm{C}$, and the precipitation was $11.2 \mathrm{~mm}$ in November, which was $2.4 \mathrm{~mm}$ in December.

Compared to the days of other years, 1 December of 2018 had the highest concentration of particulate matter of 330 $\mu \mathrm{g} / \mathrm{m}^{3}$. There was only a day ( $2^{\text {nd }}$ of December) which did not exceed the air quality standard and all other days exceeded the amount by 3 times or more than the standard. This month received only $1 \mathrm{~mm}$ of precipitation and had an average temperature of $-20.3^{\circ} \mathrm{C}$.

Most days of November 2019 were classified as normal in terms of air quality index and there were 7 days which reached the highest point of $80 \mu \mathrm{g} / \mathrm{m}^{3}$. This month also had the lowest amount of $\mathrm{PM}_{2.5}$ concentration compared to the other years. The average temperature was $-10^{\circ} \mathrm{C}$ and received $6.8 \mathrm{~mm}$ of precipitation.

Even though the daily $\mathrm{PM}_{2.5}$ concentration in December 2019 was higher than the air quality standard, it was lower than in the same period of other years. The average temperature was $-17.6^{\circ} \mathrm{C}$ and the precipitation was $2 \mathrm{~mm}$.

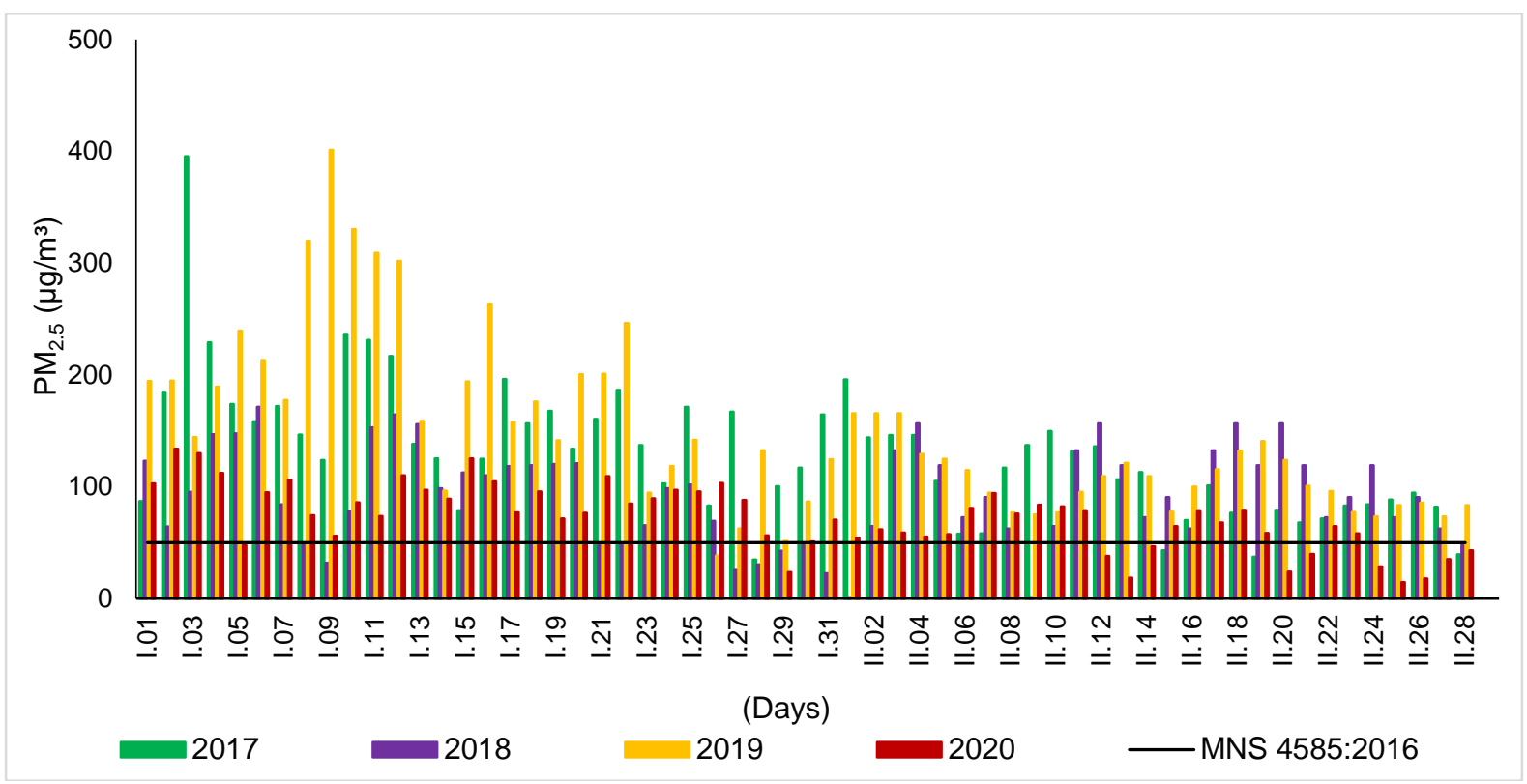

Figure 8. Daily concentration of PM 2.5 from 1 January to 28 February, 2017-2020

Figure 8 shows daily concentration of $\mathrm{PM}_{2.5}$ in January and February of 2017-2020 in comparison with air quality standard (50 $\mu \mathrm{g} / \mathrm{m}^{3}$ ), which is indicated by the horizontal line. In January 2017, the concentration of particulate matter was 4 times higher than the standard. The average temperature of the month was $-20^{\circ} \mathrm{C}$ and received $0.8 \mathrm{~mm}$ precipitation. The amount of concentration decreased in February; however, the daily amount for 26 days was measured above the standard line.
February had an average temperature of $13.7^{\circ} \mathrm{C}$ and received $0.2 \mathrm{~mm}$ of precipitation.

Compared to 2017 and 2019, January 2018 had relatively less $\mathrm{PM}_{2.5}$ concentration, yet the number of days, which were measured above the standards, was 23. The average monthly temperature reached $-22.4^{\circ} \mathrm{C}$ and precipitation was $1.8 \mathrm{~mm}$.

If we compare the same period of 2019 with other years, the amount of $\mathrm{PM}_{2.5}$ was higher and it even reached $400 \mu \mathrm{g} / \mathrm{m}^{3}$ on 9 
January, which indicates the monthly highest point. The average temperature reached $17.9^{\circ} \mathrm{C}$ and the amount of precipitation was 1.2 mm for January. In February of this year, the amount of $\mathrm{PM}_{2.5}$ decreased, but still it was above the permissible standards. It had an average temperature of $-16.7^{\circ} \mathrm{C}$ and there was no precipitation.

January 2020 had an average temperature of $-17.4^{\circ} \mathrm{C}$ and received $0.88 \mathrm{~mm}$ of precipitation and the amount of $\mathrm{PM}_{2.5}$ concentrated was less than in the same period of other years, yet it had many points exceeding the air quality standards. In fact, February also had less concentration of $\mathrm{PM}_{2.5}$ compared to the same period of other years and most of the days had normal air quality indexes. It had an average temperature of $-13.4^{\circ} \mathrm{C}$ and received $8.8 \mathrm{~mm}$ of precipitation.

For Ulaanbaatar city, January had been considered the most polluted month for the last several years; nonetheless, January of 2020 had less amounts of $\mathrm{PM}_{2.5}$ concentrations than in the other years, as shown in Figure 8.

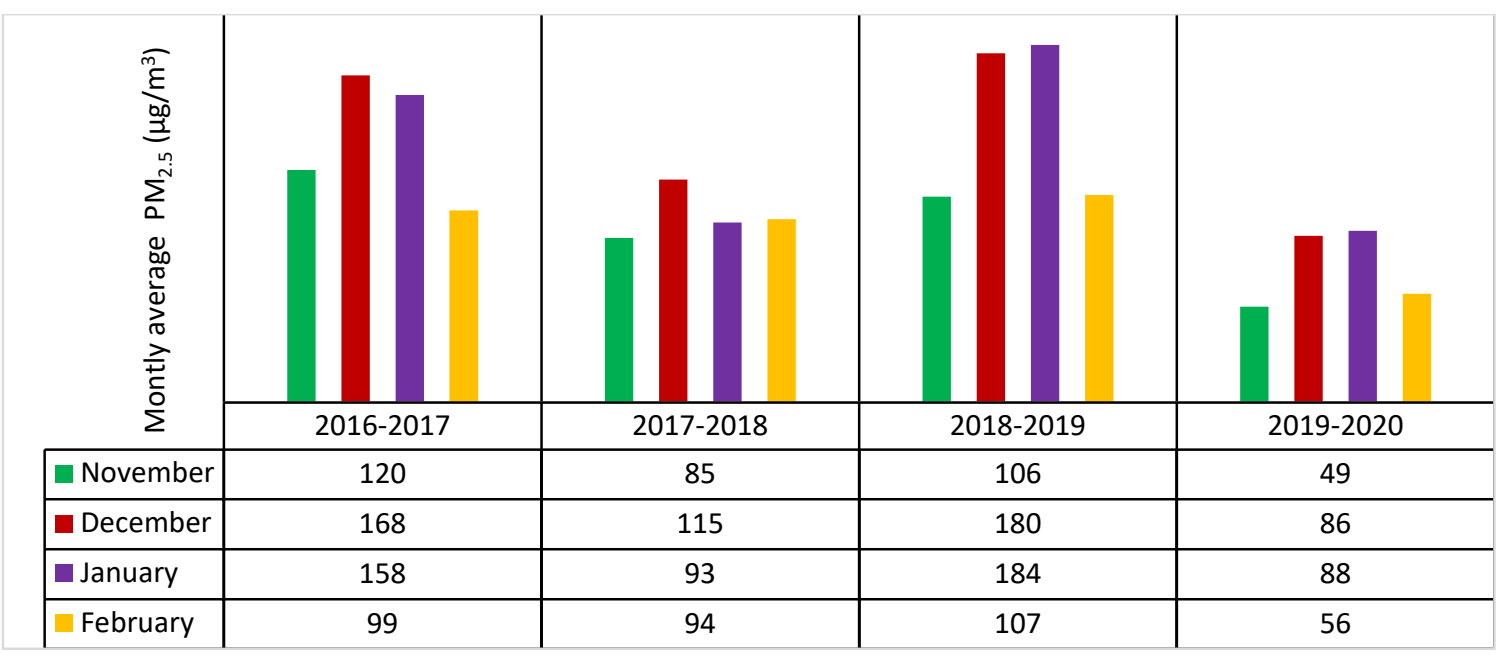

Figure 9. Monthly averages of $P M_{2.5}$ concentration among 4 consecutive winters (2016-2019)

In Figure 9, the monthly averages of the four consecutive winters with the highest concentration of $\mathrm{PM}_{2.5}$ are illustrated and compared with each other.

According to the above illustration, the point shown for November 2019 (green column) was 2.2 times less than in 2016, 0.3 times less than in 2017 and twice less than in 2018 , and the monthly average did not exceed the air quality standard $\left(50 \mu \mathrm{g} / \mathrm{m}^{3}\right)$.

Furthermore, the amount of $\mathrm{PM}_{2.5}$ concentration in December 2019 (red column) was also 2.3 times less than in 2016, 0.3 times less than in 2017, and three times less than in 2018, whereas $\mathrm{PM}_{2.5}$ concentration in January 2020 was 2.2 times less than in 2017, it was the same as in 2018, and two times less than in 2019.

For February 2020, the amount of concentration was 0.4 times less than in 2017 ,
0.3 times less than in 2018, two times less than that of 2019. Therefore, based on the above statistics, in the consecutive months of November 2019 through February 2020, there was a reduction in the amount of $\mathrm{PM}_{2.5}$ concentration by $50-80 \mu \mathrm{g} / \mathrm{m}^{3}$ compared to the same months of the other years.

In this study, we mainly focused on the cold winter months with the highest concentration of $\mathrm{PM}_{2.5}$. As a result of the research, we concluded that the concentration of fine particulate matter in Ulaanbaatar for the period from November 2019 through February 2020 decreased by 44 per cent compared to previous years and the duration of its dispersion was shortened as well.

Ulaanbaatar has been identified as one of the 50 cities of the world where air pollution had dropped due to the COVID-19 lockdown, as is shown in a joint study conducted by 
Daniella Rodriguez-Urrego and Leonardo Rodrhguez-Urrego [15].

The study compares the AQI levels before and after the quarantine period, based on air quality monitoring stations available in each city. Some cities such as Lisbon, Warsaw and Tehran have improved AQI level mainly due to "demobilized automobiles and shut down factories", which created the most pollution. However, some capitals such as Prague, Vienna and Bratislava, which normally had a very good quality of air, shifted from good to moderate levels of AQI. The reason for this shift is observed to be the effects of proximity to each other, wind and fire.

About 70 per cent of air pollution of Ulaanbaatar, Mongolia is being produced by households in the "ger" districts, whose primary source of energy for heating and cooking is coal. The level of air pollution is

\section{CONCLUSIONS}

According to the collected data samplings and analysis from 2016 to October 2020 by $\mathrm{PM}_{2.5}$ sensor of the single point monitoring station located at Building-3 of the National University of Mongolia, the following conclusions are made:

Although November of 2016-2018 had the highest amount of $\mathrm{PM}_{2.5}$ over air quality standards for most of the days, November 2019 had the lowest amount of PM2.5 concentration (49 $\mu \mathrm{g} / \mathrm{m}^{3}$ ), occurring six months after the raw coal ban. Furthermore, in December through February of previous consecutive years, the amount of $\mathrm{PM}_{2.5}$ was high; nevertheless, $\mathrm{PM}_{2.5}$ concentration in November and December of 2019, and January and February of 2020 decreased rapidly and the length of the pollution period had shortened.

Based on the comparisons made among 3 consecutive cold periods of 2016-2017, 2017-

\section{REFERENCES}

1. Institute of Meteorology and Hydrology. Climate change and resource research department., (2017) Available online: more likely to increase during the lockdown of COVID-19. Due to an emergency action taken by the Mongolian government, which required all residents to stay home except for mandatory cases, people spent less time outdoors and more indoors, thus, fossil fuel burning could have been possibly increased as well as air pollution. However, the fact that the amount of PM2.5 concentration significantly decreased compared to previous years was not due to the COVID outbreak related actions but it was thanks to Resolution 62 of the Mongolian government, which banned the burning of raw coal and required only the use of coal by-product. In another study, it was also found that the concentration of PM10 and PM2.5 during winter 2019-2020 decreased by 46-55 per cent, compared to previous years [16], which complies with our study as well.

2018, and 2018-2019, the concentration of fine particulate matter always exceeded 2-3 times over the air quality standard. However, we observed that in November through February of 2019-2020, $\mathrm{PM}_{2.5}$ concentration rapidly decreased by 44 per cent compared to the same period of previous years.

The newly implemented regulation of coal briquette burning as a primary source of heating and cooking for households in ger districts played a crucial role in dropping outdoor concentration of fine particulate matter in winter 2019-2020 to the level near the national air quality standard $\left(50 \mu \mathrm{g} / \mathrm{m}^{3} 24\right.$-hour mean) in Ulaanbaatar city.

Acknowledgments: The study was funded by SSA_2020/26 of the Ministry of Education and $\overline{\text { Science and the Mongolian }}$ Foundation for Science and Technology.

http://tsag-agaar.gov.mn/ (accessed on 10 October 2020).

2. Batima, Punsalmaa, et al. "Observed climate change in Mongolia." Assess Imp 
Adapt Clim Change Work Pap 12. (2005): pp. 1-26.

3. UNICEF. Mongolia's air pollution crisis: A call to action to protect children's health report. (2016) Available online: https://www.unicef.org/mongolia/media/9 11/file/Agaariin_bohirdol_report_mn.pdf (accessed on 12 October 2020).

4. National statistical commission. (2020) Available online: http://1212.mn/BookLibraryDownload.ash x?url=UB_health_airpolution_2020.pdf (accessed on 15 October 2020).

5. National statistical commission. (2019) Available online: http://1212.mn/BookLibraryDownload.ash x?url=UB_health_airpolution_2019.pdf\&l $\underline{n}=\mathrm{Mn}$ (accessed on 15 October 2019).

6. Mongolian Air Quality Standard (MNS 4585:2016). Available online: http://www.agaar.mn/article-view/546 (accessed on 12 March 2018).

7. World Health Organization Air quality guidelines for particulate matter, ozone, nitrogen dioxide and sulfur dioxide: global update (2005): summary of risk assessment. Geneva World Health Organ. World Health Organization, 1-22. Available online: https://apps.who.int/iris/bitstream/handle/ 10665/69477/WHO_SDE_PHE_OEH_06. 02_eng.pdf (accessed on 17 October 2020).

8. Ulaanbaatar statistical Department., (2020) Available online: http://ubstat.mn/JobTables.aspx (accessed on 19 October 2020).

9. Saglani, Sejal, et al. "Early detection of airway wall remodeling and eosinophilic inflammation in preschool wheezers." American journal of respiratory and critical care medicine 176.9 (2007): pp. 858-864.
10. World Economic Forum. Every Breath Matters campaign. (2019) Available online:

https://www.weforum.org/agenda/2019/06 /10-facts-about-air-pollution-on-worldenvironment-day (accessed on 19 October 2020).

11. Sonomdagva, Chonokhuu, Byambaa Batdelger, and Byambatseren Chuluunpurev. "Characteristics of PM10 and PM2. 5 in the Ambient Air of Ulaanbaatar, Mongolia." International Journal of Environmental Science and Development 7.11 (2016): p. 827.

12. Nakao, Motoyuki, et al. "Effects of air pollution and seasons on health-related quality of life of Mongolian adults living in Ulaanbaatar: cross-sectional studies." BMC Public Health 17.1 (2017): pp. 1-12.

13. Mongolian Integrated legal information system. Available online: https://www.legalinfo.mn/law/details/154 15 ?lawid=15415 (accessed on 20 October 2021).

14. Nakayama, Tomoki, et al. "Development and evaluation of a palm-sized optical PM2.5 sensor." Aerosol Science and Technology 52.1 (2018): pp. 2-12.

15. Rodríguez-Urrego, Daniella, and Leonardo Rodríguez-Urrego. "Air quality during the COVID-19: PM2. 5 analysis in the 50 most polluted capital cities in the world." Environmental Pollution (2020): 115042.

16. Ganbat, Gantuya, Tseren-Ochir SoyolErdene, and Batbayar Jadamba. "Recent Improvement in Particulate Matter (PM) Pollution in Ulaanbaatar, Mongolia." Aerosol and Air Quality Research 20.10 (2020): pp. 2280-2288. 